\title{
Purification and Characterization of Cellulase from Aspergillus niger Causing Soft Rot of White Yam in Three Environments in Nigeria
}

\author{
Ajibade Gabriel Adegboyega, Abdulsalami Mohammed Sani, Denwe Samuel Dangwel, \\ Oladapo Elizabeth Omolola*, Popoola Omokunmi
}

Department of Biological Sciences, Faculty of Sciences, Nigeria Defence Academy, Kaduna, Nigeria

Email address:

gaajibade@nda.edu.ng (A. G. Adegboyega), msabdulsalami@nda.edu.ng (A. M. Sani), msdenwe@nda.edu.ng (D. S. Dangwel), eooladapo@nda.edu.ng (O. E. Omolola), kunmipopoola@yahoo.com (P. Omokunmi)

${ }^{*}$ Corresponding author

\section{To cite this article:}

Ajibade Gabriel Adegboyega, Abdulsalami Mohammed Sani, Denwe Samuel Dangwel, Oladapo Elizabeth Omolola, Popoola Omokunmi. Purification and Characterization of Cellulase from Aspergillus niger Causing Soft Rot of White Yam in Three Environments in Nigeria. International Journal of Applied Agricultural Sciences. Vol. 5, No. 4, 2019, pp. 82-89. doi: 10.11648/j.ijaas.20190504.11

Received: May 4, 2019; Accepted: June 26, 2019; Published: July 30, 2019

\begin{abstract}
Aspergillus niger is abundant in most tropical soils and invariably, on the surface of yam tubers while still attached to the plant and on the root hairs during harvesting or storage. Naturally, the peridermic surface of the tubers function to exclude pathogen but damage caused by accidental incision or cut surface during weeding, insect attack and harvesting provide avenue for the infection. Aspergillus niger isolated from diseased yam in three zones in Nigeria synthesized cellulase which caused soft rot of the yam within nine days of inoculation. Microscopic and molecular analyses revealed two isolates of A. niger, $\mathrm{P}_{1}$ and $\mathrm{P}_{2}$, from different environment produced cellulase enzymes in significantly different proportions. When protein extracts from the infection were subjected to molecular exclusion chromatography, three peaks of absorption (A, B and C) were produced with only the components of peak A showing cellulase activity. Further fractionation of the components of peak A produced two absorption peaks ( $\mathrm{Aa}$ and $\mathrm{Ab}$ ) with only component Aa showing Cellulase activity. A. niger isolates, $\mathrm{P}_{1}$ and $\mathrm{P}_{2}$ showed considerable differences in the intensity of cellulase production suggesting that multiple strains of A. niger in the soil of yam-growing environments synthesized cellulase as transcriptional products in different manner underscoring the effect of physico - chemical properties of the soil on infectivity and virulence of the organism during yam rot.
\end{abstract}

Keywords: Aspergillus niger, Cellulase, Soft Rot

\section{Introduction}

The black mould rot of yam is caused by Aspergillus niger. The infection is characterized by decay of entire tuber during which the cells collapse with loss of integrity as a functional unit. In host-pathogen interaction, the ability of the pathogen to produce extracellular enzymes capable of degrading the host tissues is one of the more obvious properties influencing virulence [1]. A. niger is abundant in most tropical soils and, invariably, on the surface of yam tubers while still attached to the plant and on the root hairs during harvesting or storage. Naturally, the peridermic surface of the tubers function to exclude pathogen but damage caused by accidental incision or cut surface during weeding, insect attack and harvesting provide avenue for the infection. According to the study [2], chemotaxonomic characteristic is a virulence factor with variation arising from a multiplicity of factors including the nature of soil ecology and production of primary and secondary metabolites such as enzymes, aflatoxins and phytoalexins [1].

A. niger is able to synthesize cellulase enzyme complex that breaks down cellulose of the cell wall components into glucose [2] giving the organism access to utilize the tissues for its metabolism. According to these studies [1, 10], Cellulase $\{$ EC 3.2.1.4\} secreted by pathogens play a critical role in softening and disintegrating the cell wall material. Cellulase facilitates the penetration and spread of the pathogen in the host and causes the collapse and 
disintegration of the cellular structure thereby aiding the pathogen in the propagation of the disease $[3,9]$.

The environment in which a pathogen grows dictates to a large extent, the quality and nature of enzymes involved in the infection and degradation of the host tissues. This study examined the pattern of synthesis of cellulase as transcriptional product of $A$. niger causing soft rot of yam from three different environments in Nigeria.

\section{Materials and Methods}

\subsection{Organism and Culture Condition}

A. niger was obtained from diseased yam from three yam growing zones in Nigeria; Abuja, Iwo and Owerri. It was grown in Petri dishes containing Potato Dextrose Agar (PDA) medium in aseptic conditions. The plates were incubated at ambient temperature and then subcultured on the same media plates and the fungi spores from $72 \mathrm{hr}$ - old culture was used to inoculate healthy yam tubers.

\subsection{Extraction and Purification of Enzymes}

Inoculated and uninoculate tissues of yam in the three environment were extracted for enzyme activity every $24 \mathrm{hr}$. The extractant was $0.5 \mathrm{~N} \mathrm{NaCl}$ in $0.02 \mathrm{M}$ citrate phosphate buffer (pH 5.0).

\subsection{Precipitation and Dialysis of Enzyme}

The enzyme was partially purified by ultracentrifugation followed by ammonium sulphate precipitation and dialysis for 24 hours at $4^{\circ} \mathrm{C}$ against the buffer ( $\mathrm{pH}$ 6.0) using acetylated cellophane tubing $[4,5]$. The protein content was determined by the method of these studies $[5,6]$.

\subsection{Cellulase Assay}

The assay for Cellulase was determined by the modified Dinitro-Salicylic Acid (DNSA) method of the study [4]. Glucose was used as standard and one unit of cellulase activity was defined as the amount of enzyme in $1 \mathrm{ml}$ of the reaction mixture required to liberate reducing sugar equivalent to $10 \mathrm{mg}$ glucose in one minute under the specific condition of the reaction on application of enzyme.

\subsection{G-75 Column Calibration}

A vertical glass tube chromatography column (640 x $25 \mathrm{~mm}$ ) was calibrated with proteins of known molecular weights according to the study [4], and employed for the fractionation of the enzyme. $10 \mathrm{ml}$ of dialysed enzyme concentrate was applied to the column and eluted with $0.02 \mathrm{M}$ citrate phosphate buffer ( $\mathrm{pH}$ 6.0). Fractions were collected $(5 \mathrm{ml}$ per tube) and protein content determined at $280 \mathrm{nM}$.

\subsection{Further Fractionation of Enzyme by Ion-exchange Chromatography}

Eluted fractions which showed appreciable enzyme activity after gel fractionation was combined and $10 \mathrm{ml}$ of enzyme concentrate applied to the column $(280 \times 250 \mathrm{~mm})$ of Sephadex CM G-50 and the fraction were collected and measured for protein content and cellulase assay. The effect of physico-chemical factors of soil on purified enzyme (G-75 factor) was determined. The effects of temperature, $\mathrm{pH}$ and cations $\left(\mathrm{k}+, \mathrm{Na}+\right.$ and $\left.\mathrm{Ca}^{2+}\right)$ on enzyme activity in the three yam growing zones were determine by the method of the study [6].

\subsection{Morphological Identification}

Each of the $A$. niger isolated from decayed yam in the three environments were identified using the manuals about the genus Aspergillus [6]. Slides were stained with cotton blue and mounted in Lactophenol. Photomicrographs were taken with digital canon camera (A550, 7.1 megapixels).

\subsection{Preparation of Genomic DNA}

The method [7] was used for DNA isolation. Dissolved generic DNA samples from each of the $A$. niger isolates P1 P6 were stored at $-200^{\circ} \mathrm{C}$.

\subsection{DNA Amplification and Electrophoresis}

Polymerase Chain Reaction (PCR) was carried out on the isolated DNA of $A$. niger from the different environments using the amplification kit and automated programmable PCR thermal cylinder with ITS 1 and ITS 4 as primers at the DNA laboratory, Ungwan Sarki, Kaduna, Nigeria. Amplified fragments P1, P2, P3, P4, P5 and P6 were each separated in agarose gel in the electrophoretic chamber and Chemidoc was used to produce camera snaps of DNA band pattern according to the method of the study [8].

\section{Results}

\subsection{Infection of Yam Tissues by A. niger}

A. niger caused extensive degradation of healthy yam tissues at the point of infection irrespective of the source of yam. Extensive sporulation occurred at the point of inoculation. Tubers aseptically inoculated with sterile water lacked sporulation. Infection of the Yam tissues was very slow in yams placed on bare ground devoid of soil.

When the organisms from different yam-growing zones were sub-cultured on Potato Dextrose Agar (PDA), there were variations in the cultural appearance of conidiospores of $A$. niger appearing on agar plates. Structural morphologies of the isolates also showed some differential characteristics.

\subsection{Microscopic Examination of A. niger}

Microscopy of P1 and P2 isolates showed a large black conidial that are arranged in a globose biseriate head arising from a spherical conidiophore. The black coloured colonies were identified as $A$. niger based on the structural morphologies as observed under the light microscope. It was observed that the isolates possessed distinct conidiophores terminated by a swollen vesicle bearing flask-shaped 
phialides. The black-coloured colonies consist of a compact white or yellow basal felt covered by a dense layer of darkbrown to black conidial heads similar to the observation of the study [8]. The ones with the yellow basal felt (marked P1 isolates) were isolated from Zone 1 (Abuja) while the ones with yellow and white basal felt (marked P1 and P2) were both isolated from Zones 2 and 3 (Iwo and Owerri).

\subsubsection{Macroscopic Characterization of P1}

Colonies on PDA plates attained $31 \mathrm{~mm}$ in diameter in 7 days at $27^{\circ} \mathrm{C}$ colony coloured brown to dark, reverse is light yellow and transparent (Figure 1).

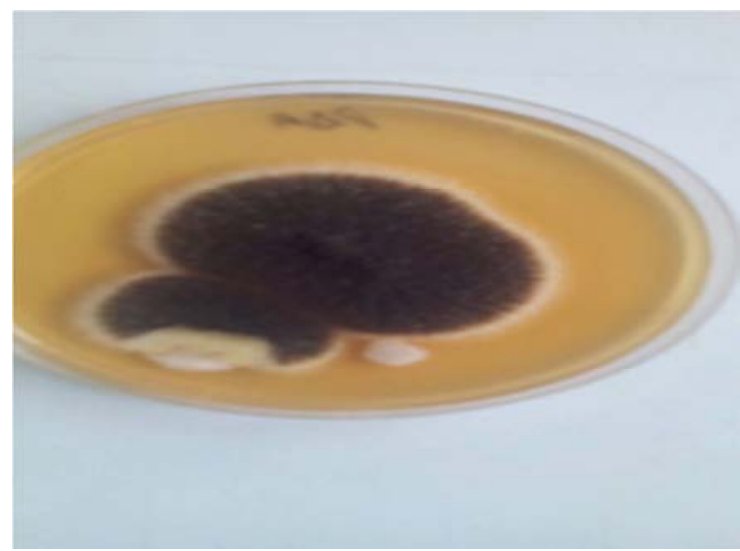

Figure 1. Growth of A. niger Strain Isolate P1 from Infected Tubers on PDA Plates.

\subsubsection{Microscopic Characterization of P1}

The conidia head on PDA radiate, $80-100 \mu$ in diameter, conidiophores hyaline, smooth, $100-200 \mu$ long and $4-5 \mu$ wide with $1 \mu$ thick wall. Vesicle was globose and $10-18 \mu$ in diameter. Matulae were ampuliform $5-8 \mu$ by $1.5-2 \mu$ wide. Phialides ampuliform, $5-7 \mu$ by $1.5-2 \mu$ wide. Conidia were globose and $1.5-2.5 \mu$ in diameter (Figure 2). The conidia head was compact columnar, $80-160 \mu$ long by $1.5-2 \mu$ wide and phialides ampuliform $5-8 \mu$ by $1.5-2 \mu$ wide. Conidia were also globose, $1.6-2.5 \mu$ in diameter (Figure 3 ).

\subsubsection{Macroscopic Characterization of P2}

The conidia based on PDA plates attained $55 \mathrm{~mm}$ after 7 days at 30oc colony colour was black (Figure 2 and 3). The reverse side was mostly hyaline to light yellow.

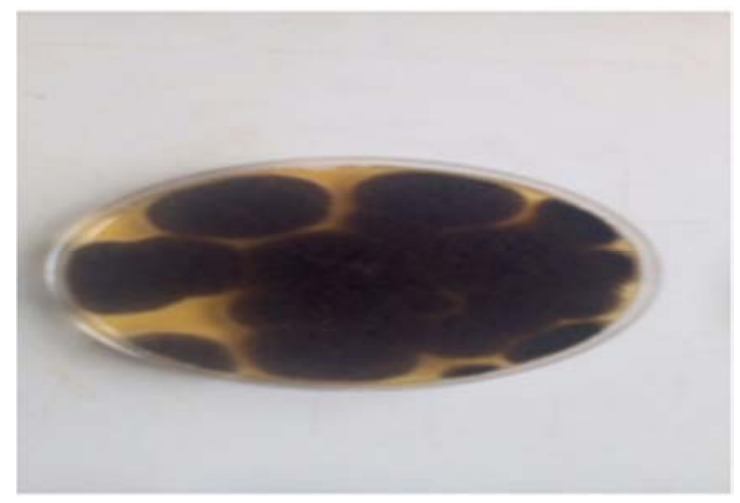

Figure 2. Growth of A. niger Isolate P2 from Infected Yam Tubers.

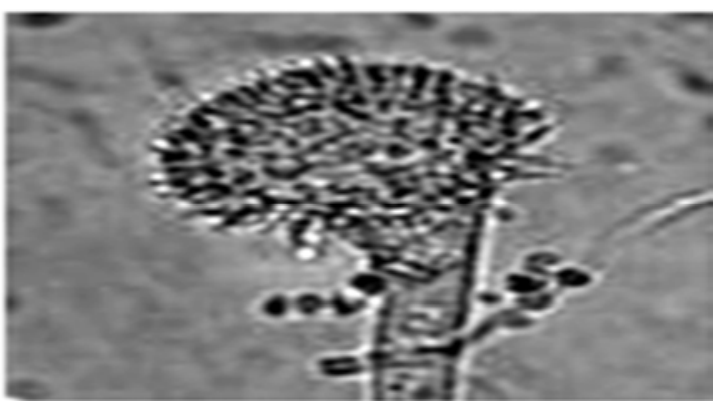

Figure 3. Microscopic Features of A. niger Isolate P2 Stained with Lactophenol in Cotton Blue (Mag.40x).

\subsubsection{Microscopic Characterization of P2}

Conidial heads on PDA plates radiate conidiophores that are $300-400 \mu$ long, $8-12 \mu$ wide with $1.5-2.5 \mu$ thick wall. Vesicles are globose and $3.5-4 \mu$ in diameter. Conidial heads are also globose $3.5-4 \mu$ in diameter. Phialides are ampuliform and metulae club shaped (Figure 4).

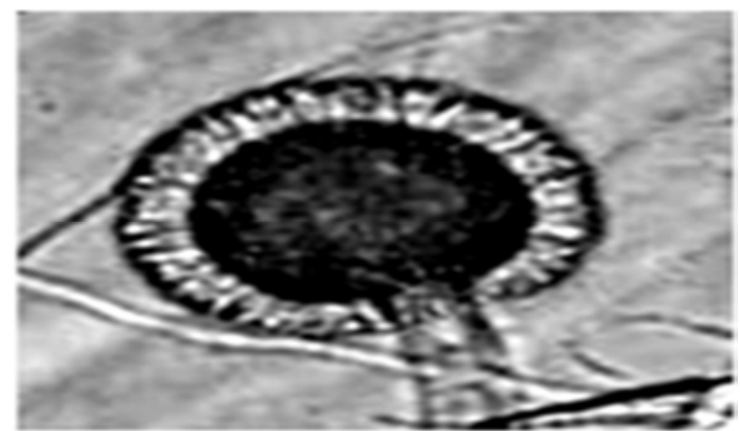

Figure 4. Microscopic Features of A. niger Isolate P2 Stained with Lactophenol in Cotton Blue (Mag.40x).

\subsection{Molecular Characterization}

The two different isolates of $A$. niger identified through their cultural, and morphological characteristics, were further characterized molecularly. When the DNA of the two isolates (P1 and P2) were prepared, quantified and amplified for agarose-gel electrophoresis, six distinct bands were observed suggesting that there are differences in the nucleotide base sequences coding in the two $A$. niger isolates for enzyme production in different isolates. The molecular detection and amplification of the gene coding for $A$. niger cellulase enzymes associated with yam rot was shown in the gel electrophoresis of the DNA fragments of A.niger isolates from different yam-growing environments. This is evident with the appearance of bands on the extracted DNA of $A$. niger as shown in Figure 5.

The extent of yam rot may depend on the sample of the $A$. niger associated with the different soil or environment. The strains of $A$. niger may vary depending on their location and the arrangement of the nucleotide sequences in the genome of the organism. This results suggest that cellulase, is associated with yam soft rot as observed from different environmental conditions and that the extent of rot is also dependent on the strain of $A$. niger that confers differences in pathology. 


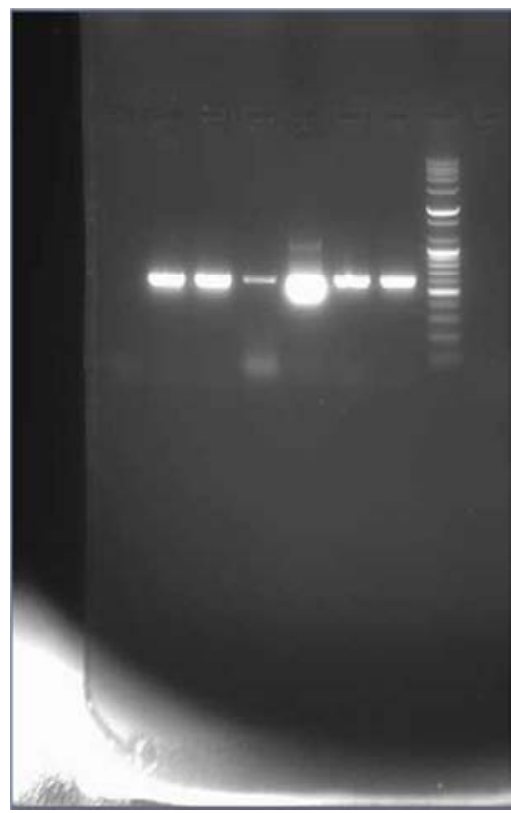

Figure 5. Agarose Gel Electrophoresis: Molecular Detection and Amplification of DNA of A. niger Isolates from Rotten Yam.

\subsection{Infection of Yam by A. niger and Enzyme Production}

Yam tissues infected with $A$. niger isolates exhibited cellulase activities (Figures 6, 7, 8, 9, 10 and 11).

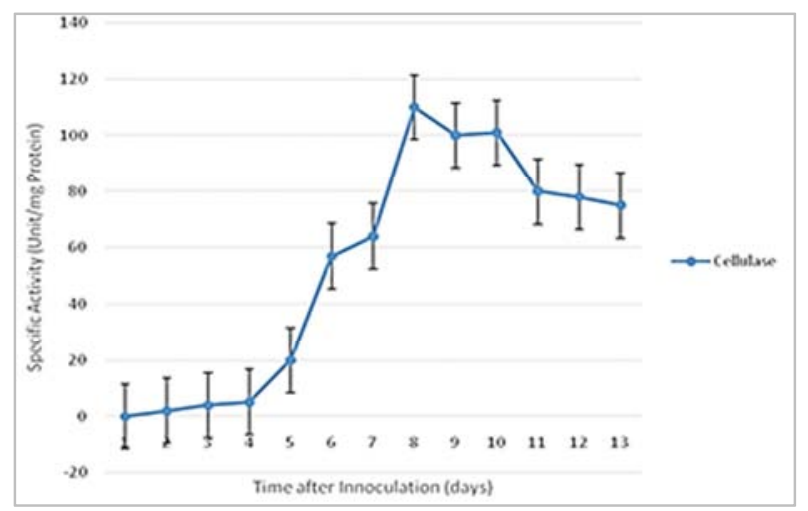

Figure 6. Enzyme Activities of Yam Tissues Infected by A. niger (P1 Isolate) in Env. 1(Abuja) by Incubation Period.

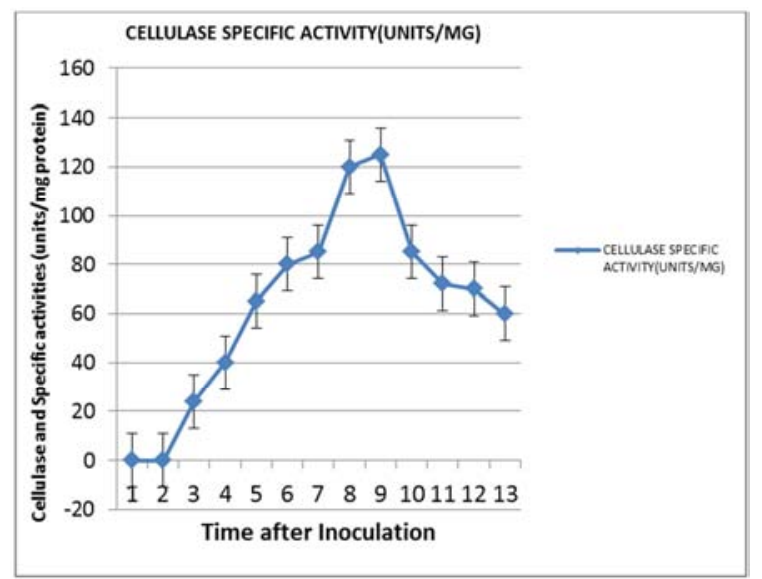

Figure 7. Enzyme Activities of Yam Tissues Infected by A. niger (P1 Isolate) Env. 2 (Iwo) by Incubation Period.

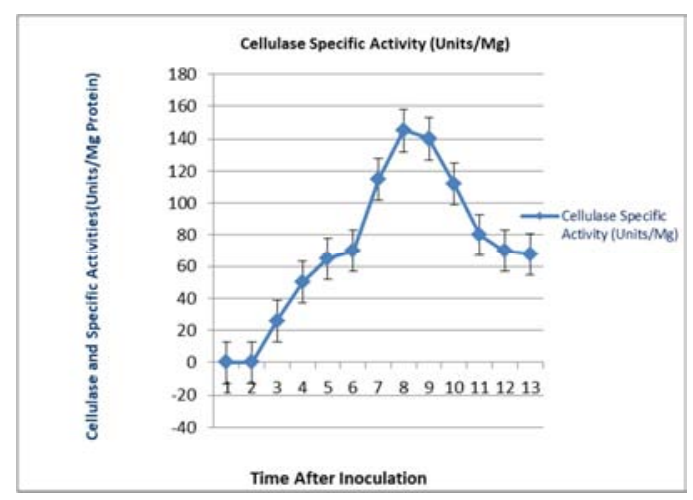

Figure 8. Enzyme Activities of Yam Tissues Infected by A. niger (P1 Isolate) Env. 3 (Owerri) by Incubation Period.

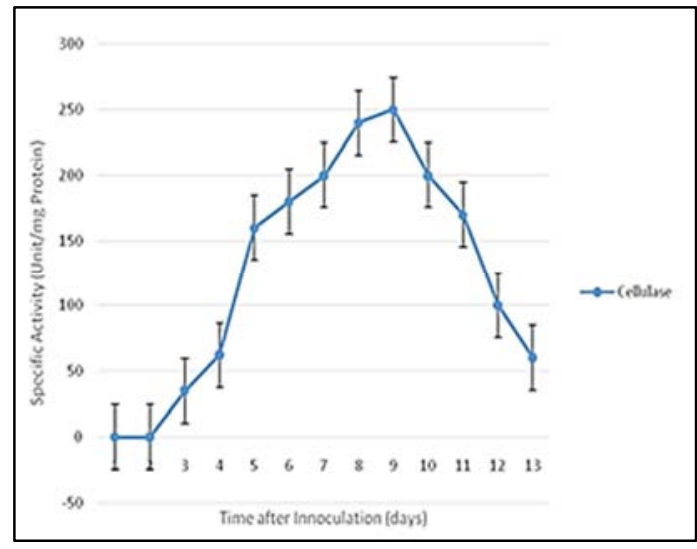

Figure 9. Enzyme Activities of Yam Tissues Infected by A. niger (P2 Isolate) Env. 3 (Iwo) by Incubation Period.

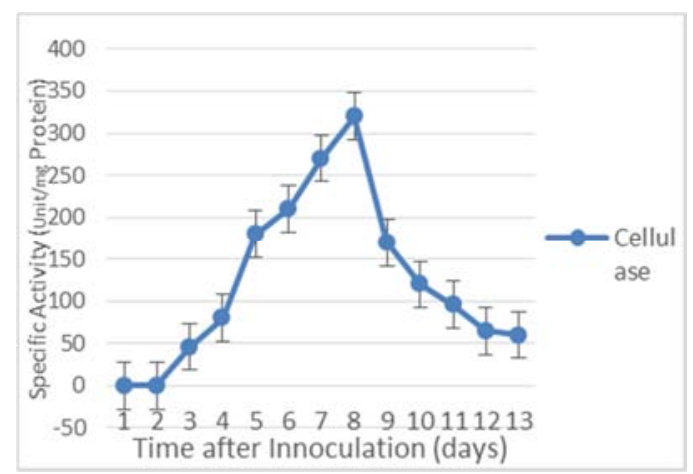

Figure 10. Enzyme Activities of Yam Tubers Infected by A. niger (P2 Isolate) in Env. 3 (OWERRI) by Incubation Period.

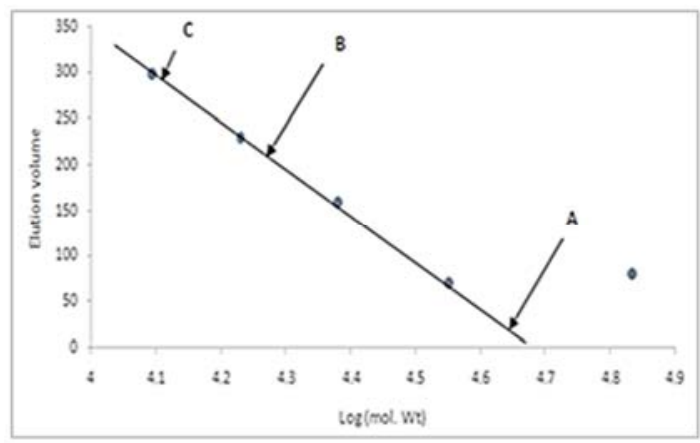

Figure 11. Elution Volume against log (M.WT) for proteins in Peaks A, B and C Calibrated by a Gel Filtration with Sephadex G-75. 
Generally, the activity of each of the enzymes increased with the intensity of infection. Uninfected yam tissues lacked any appreciable decline in the infection of yam. In Zone 1 (Figure 7) the activity of cellulase increased progressively and continued until the eight day where it reached a maximum and in the ninth day when it started to decline. However, enzyme activity of $A$. niger from zones 2 and 3 could be noticed as from the second day of inoculation. Cellulase was the first to be detected in appreciable quantity. The activity of enzymes in yam Zone 2 continuously increased to the tenth day when it started to decline (Figure 7). An almost similar pattern of increase and decline was observed in yams infected with $A$. niger in yam Zone 3 (Figure 9).

The nature of the soil around which the tuber is grown or harvested and their physico-chemical properties was observed to contribute to the intensity of enzyme production, infectivity and tuber damage. Sporulation of A. niger and yam rot was very slow when the yam was placed on bare ground. In some cases, sporulation was restricted to the zone of inoculation and rotting took a longer time than when the yam was damaged while attached to the plant or placed on the soil in ambient conditions after harvest underlining the influence of soil ecology on infectivity.

\subsection{Purification of Enzymes; Enzyme Separation on Sephadex; G-75 and CM G-50}

Fractionation of the enzyme concentrate on Sephadex G75 produced three absorption peaks marked $\mathrm{A}, \mathrm{B}$ and $\mathrm{C}$. (Figure 12). The molecular weights of the components estimated from the calibration using their respective elution volumes are about 44,670 (Peak A), 17,780 (Peak B) and 12,590 (Peak C). The activities of cellulase were detected only in Peak A. Further fractionation of Component A on CM-Sephadex CM-C50 gave two new absorption peaks marked $(\mathrm{Aa})$ and $(\mathrm{Ab})$ respectively (Figure 13). Similarly, the activity of cellulase was detected only in Peak (Aa).

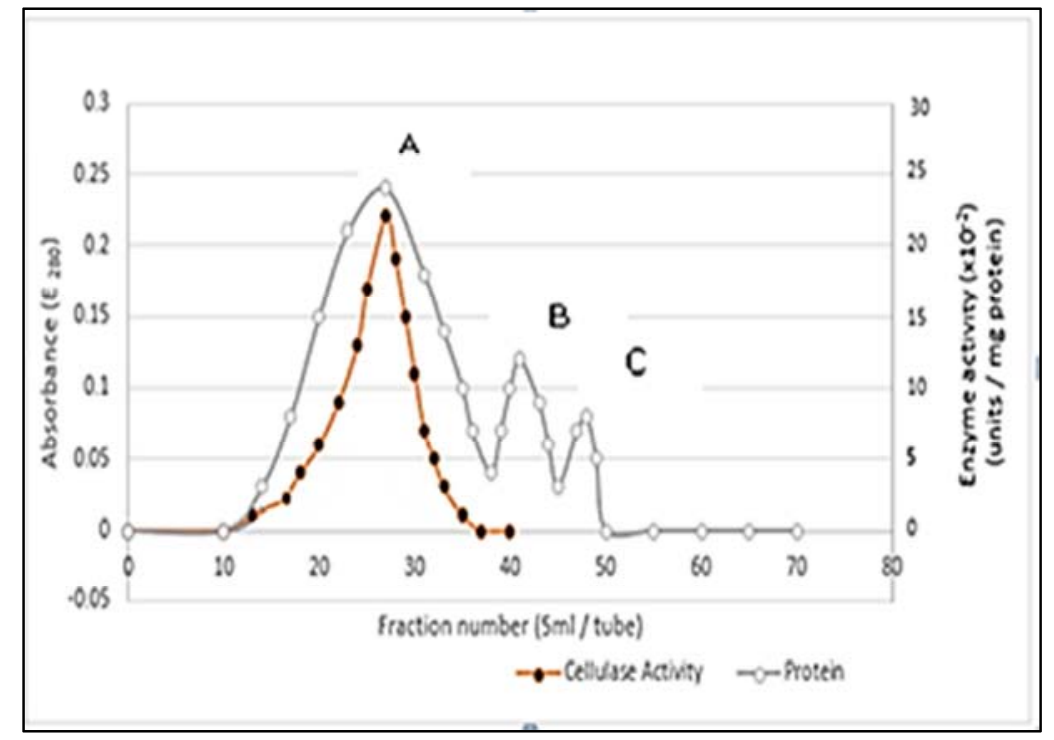

Figure 12. Separation of Protein in the Concentrated Extract of A.niger Infected Yam Tissues by Molecular Exclusion Chromatography and the Enzyme Activity of the Fraction towards Pectin and CM-cellulase.

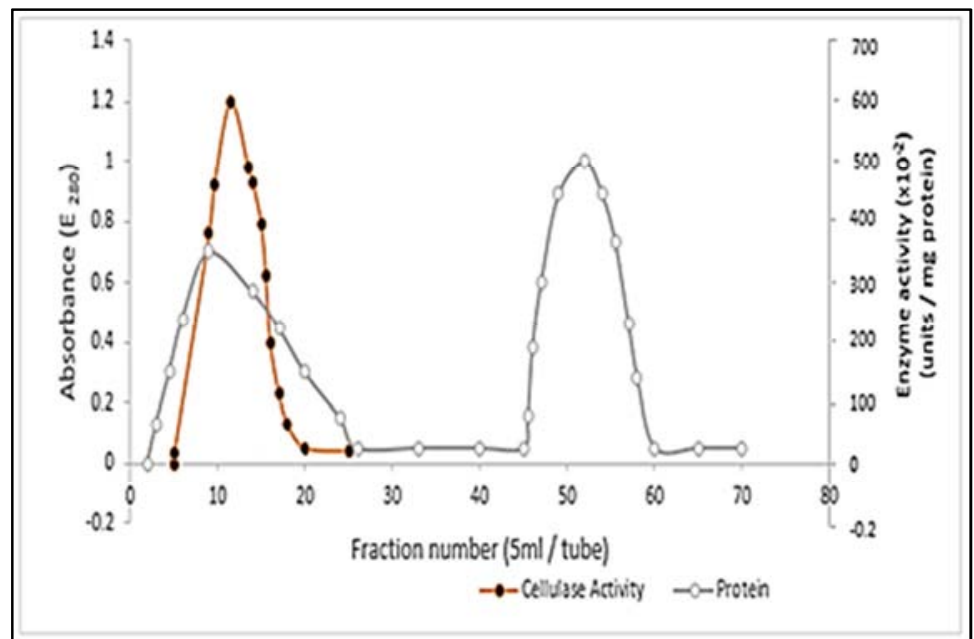

Figure 13. Separation by Ion-exchange Chromatography of High Molecular Weight Proteins (Fractions 12-50) Produced from A. niger Infected Yam Tissue Extracts by Gel Filtration and the Enzyme Activity of the Fractions towards Cellulase and Pectin. 
Table 1 shows the purification levels of cellulase. The total activity of the crude enzyme at maximum yield was 29,400 units and specific activity of 73.3 units $/ \mathrm{mg}$ protein. These mean activity values were derived from the replicates with the limit of standard error. When the proteins in the crude enzyme were subjected to ammonium sulphate precipitation, the specific activity increased to 209.3 units/mg proteins and a yield of $85.4 \%$ was obtained with 2.9 fold purification. Further fractionation and purification by molecular exclusion chromatography (Sephadex G-75) and ion-exchange chromatography (CM-Sephadex G-50) yielded much more purified enzyme up to 30.7 fold by gel filtration and 77.3 fold by ion-exchange chromatography. The specific enzyme activity increased to 2,215 units $/ \mathrm{mg}$ protein and 5,581 units/mg protein by gel filtration and ion-exchange chromatography respectively. The partially-purified cellulase enzyme, G-75 fraction was used for further analysis.

Table 1. Partial Purification of cellulose Obtained from Yam Infected with A. niger.

\begin{tabular}{llllll}
\hline Purification Step & Total Protein (mg) & Total Activity (Units) & Specific Activity (units/mg Protein) & Yield \% & Purification (Fold) \\
\hline Crude Enzyme & $402 \pm 1.0$ & $29400 \pm 1.7$ & $73.3 \pm 0.9$ & 100 & 1. \\
(NH4)2S04 Precipitate & $120 \pm 0.7$ & $25120 \pm 2.0$ & $209.3 \pm 1.0$ & 85.4 & 2.9 \\
Sephadex G-75 (Peak Aa) & $8.4 \pm 0.2$ & $18610 \pm 1.0$ & $2215.5 \pm 1.2$ & 63.3 & 30.7 \\
CM-Sephadex G-50 & $2.9 \pm 0.1$ & $16185 \pm 0.8$ & $5581.0 \pm 0.8$ & 55.1 & 77.3 \\
\hline
\end{tabular}

\subsection{Effect of Soil Temperature}

As shown in Figures 14, 15 and 16, optimum enzyme activity was observed at about $40^{\circ} \mathrm{C}$ in yam rot caused by $A$. niger in all the three zones (Zones 1, 2 and 3). Temperatures lower than $25^{\circ} \mathrm{C}$ and higher than $40^{\circ} \mathrm{C}$ resulted in diminished enzymes activity and the enzyme was almost completely inactivated at $50^{\circ} \mathrm{C}$. This indicated that the quantity of cellulase activity was completely influenced by temperature. Aspergillus niger growing on yam tubers in the three ecozones achieved maximum sporulation and enzyme activity at ambient temperature of $40^{\circ} \mathrm{C}$.

In Zone 1, the enzyme activity of cellulase was very slow at temperature of $20^{\circ} \mathrm{C}$ and $30^{\circ} \mathrm{C}$. This might have contributed to the slow sporulation at the temperatures lower than $35^{\circ} \mathrm{C}$.

In Environment 2 (Iwo), there was a steady increase in the activity of cellulase as from $20^{\circ} \mathrm{C}$ until the activity of enzyme reached a maximum at $40^{\circ} \mathrm{C}$. Enzyme activity of $A$. niger cellulase was affected by increasing soil temperature in Environment 3 (Owerri). The enzyme activity was optimum at $4^{\circ} \mathrm{C}$ after which increasing the temperature above resulted in a sharp decline of activity.

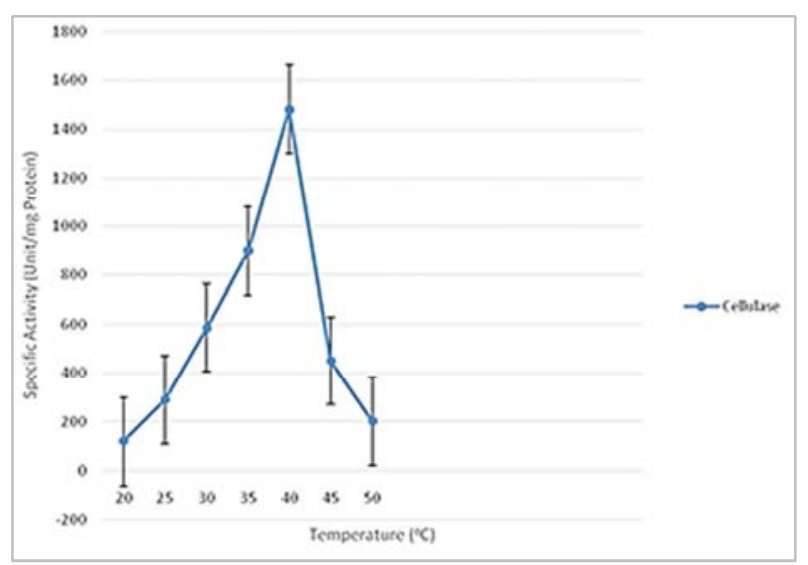

Figure 14. Effect of Soil Temperature on Cellulase Activity of Protein Extracts of Infected Yam in Env.1 (Abuja).

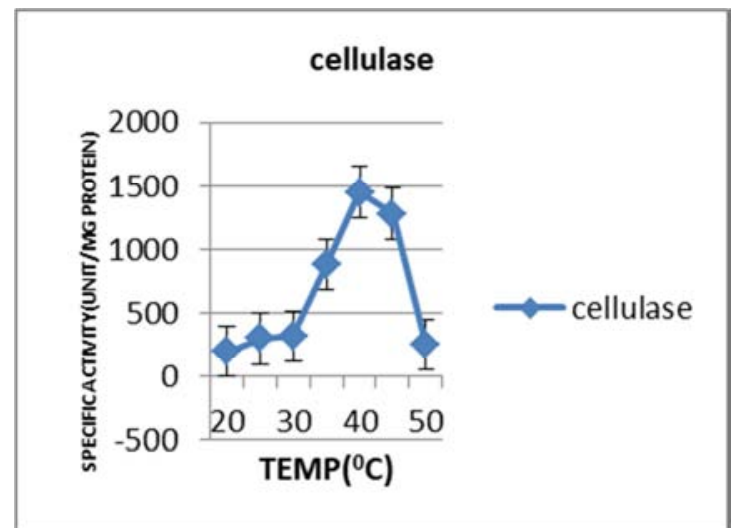

Figure 15. Effect of Soil Temperature on Enzyme Activity of Protein Extracts of Infected Yam in Env. 2 (Iwo).

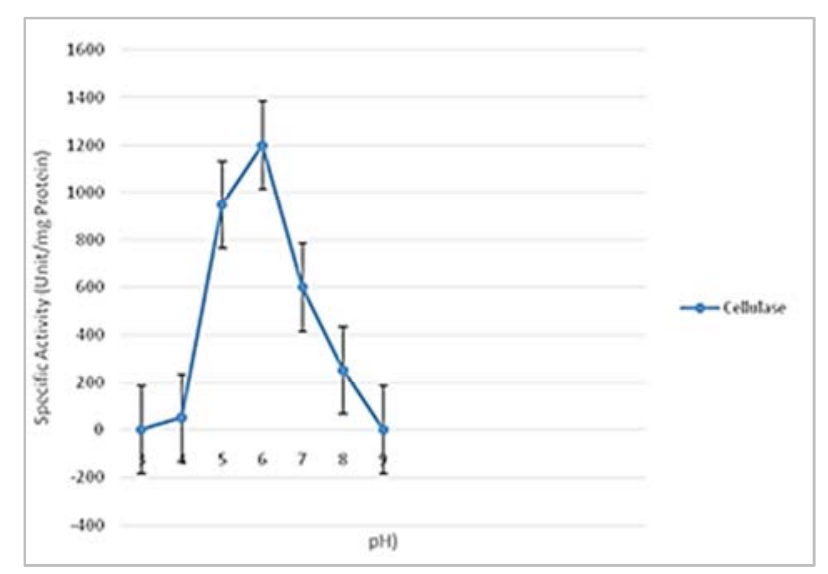

Figure 16. Effect of Soil Temperature on Enzyme Activity of Cellulase Extracts on Infected Yam in Env.3 (Owerri).

\subsection{Effect of Soil pH}

Figures 17, 18 and 19 showed that the intensity of enzyme production is greatly influenced by changes in the hydrogen ion concentration $(\mathrm{pH})$ of the soil. Optimum production occurred in slightly acidic medium of between $\mathrm{pH} 4.0$ and 6.0 in the three environments. 


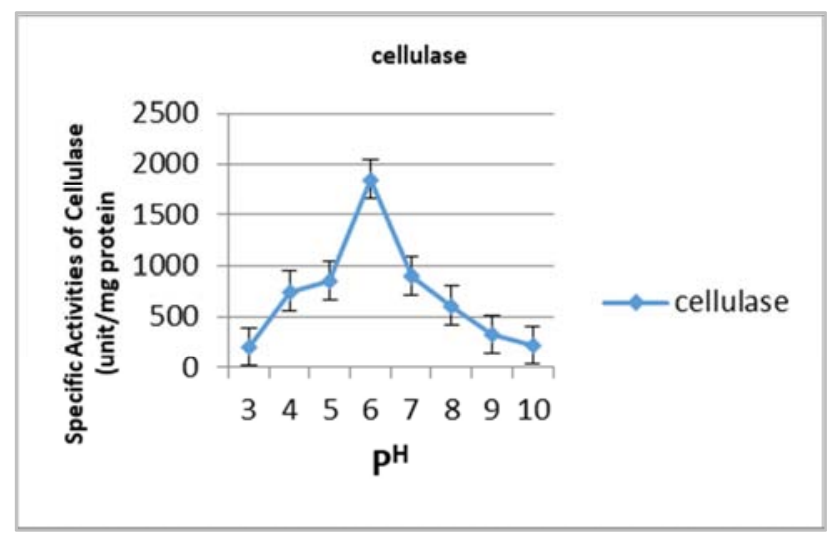

Figure 17. Effect of Soil pH on Enzyme Activity of Protein Extracts in Infected Yam from Env. 2 (Iwo).

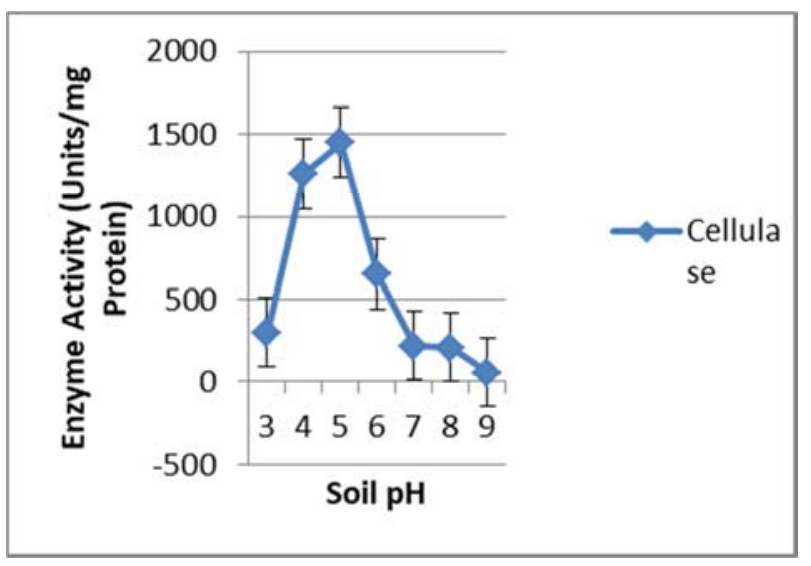

Figure 18. Effect of Soil pH on Enzyme Activity of Protein Extracts in Infected Yam from Env. 3.

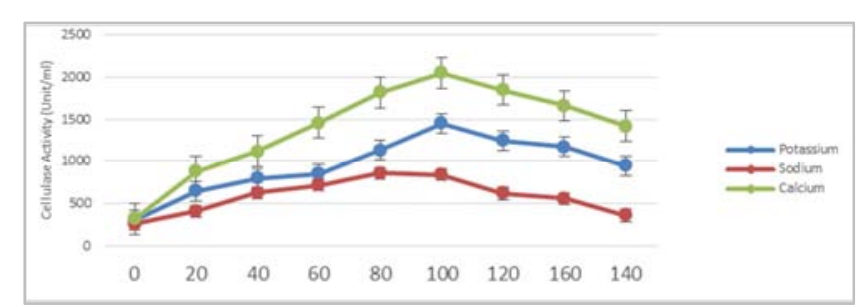

Figure 19. Effect of Cations on the Activity of Partially-Purified Cellulase ( $G$-75 Fraction).

Cellulase enzyme can tolerate high concentration of cations of up to $100 \mathrm{mM}$ for $\mathrm{Ca} 2+, \mathrm{Na} 2+$ and $\mathrm{K}+$ with simulating effects before enzyme activity began to slow down gradually.

\section{Discussion and Conclusion}

The results showed that $A$. niger caused extensive degradation of yam tissues after nine days of infection. The statistical significance is in agreement with the practical significance buttressed in the analysis of variance (ANOVA) of the mean of replicate values across the three environments which showed significant variations in the extent of cellulase produced. The sum of squares of between group was moderately high ( 23280.150 at 2,38 , df respectively). The value of $\mathrm{p}=0.48$ is less than 0.05 indicating statistical significance in the pattern of cellulase production in the infection of yam by A. niger. The results of multiple comparisons also indicated that the mean difference in the intensity of enzyme production in the three yam-growing environments studied is significant at 0.05 level.

Soil ecology has also been observed to play a prominent role in the infection process as washed yams that were placed on bare concrete floor without soil on them took a much longer time to register decay of the yam tissues.

The increase in the rate of enzyme production and infectivity might be attributed to the virulence factor of the isolate of Aspergillus niger involved in the infection which has contributed to its pathogenicity.

Identified through their cultural, microscopic and morphological characteristics, the isolates of $A$. niger labelled P1 and P2 (isolated from infected yam) were the same organisms isolated from the soil of the yam-growing areas investigated.

When the DNA of the two isolates (P1 and P2) were prepared, quantified and amplified for agarose gel electrophoresis, six distinct bands were observed suggesting that there are possibly differences in the nucleotide bases sequences in the two $A$. niger isolates in the three environments. This may also be responsible for the variations in the production of cellulase as an aid to infection of yam in the three yam-growing environments studied.

The mere fact that yam tubers placed on bare soil without the effect of the physicochemical properties of the soil ecology playing a facilitative role failed to develop appreciable sporulation and decay at the point of infection emphasized the importance of the soil ecology on infection. Yam tubers grow in the soil and when harvested usually have soil particles attached to the root hairs. The knowledge of the understanding of the physicochemical properties of the soil ecology is important to quantify the conditions that are favourable for infection and disease development.

This may provide insights into the development of measures that can be used to prevent or slow down the infection. This may also lead to the devising of mechanisms for preservation of the tubers while still attached to the plant in the soil and inhibit or slow down deterioration during storage. In a similar vein, having proper knowledge of the genetic blueprint for enzyme production by

strains of $A$. niger will increase the understanding of the organisms metabolic pathway that can be used to slow down or prevent the infection process and increase the shelf life of yam during storage. This of course, can be applied to other crops facing soft rot during storage.

\section{References}

[1] S. Araz, S. Caroline, J. Francisco, R. Mark, H. John and Z. Ayalsew. "Fungal Organisms Isolated from Rotted White Yam (Dioscorea rotundata) Tubers and Antagonistic Potential of Trichoderma harzianum against Colletotrichum Species," Agricultural research and technology open access journal, vol 10 (3): 26-28, 2017. 
[2] R. Fontana, S. Salvador, and M. Da Silveira. Influence of pectin and glucose on growth and polygalacturonase production by Aspergillus niger in solid-state cultivation. Journal of Microbiology and Biochemistry, vol 32: 371-371, 2005.

[3] A. Salami and A. Akintokun. Post-harvest enzymatic activities of healthy and infected cassava (Manihot esculenta Crantz) tubers. Emirates Journal of Food and Agriculture vol 20 (1): 01-17, 2008.

[4] P. Olutiola and P. Adejuwon. Protease in tomato fruits influenced by Fusarium oxysporum. Plant Pathology Journal vol 4(1): 43-45, 2005.

[5] D. Whitaker, K. Hanson and P. Datta. Improved procedures for preparation and characterization of Myrothecium Cellulase. Part 2. Purification procedures. Canadian Journal of Biochemistry and Physiology vol 41: 671-696, 1963.
[6] O. Lowry, N. Rosebrough, A. Farr and R. Randall. Protein measurement with the folin-phenol reagent. Journal of Biological Chemistry 193: 265-275, 1951.

[7] D. Arotupin, F. Akinyosoye and A. Onifade. Purification and characterization of pectinmethylesterase from Aspergillus repens isolated from cultivated soil. African Journal of Biotechnology vol 7(12): 1991-1998, 2008.

[8] F. Ausubel, R. Brent, R. Kingston, D. Moore, J. Seidman, J. Smith and K. Strucht. Current Protocols in Molecular Biology. John Wiley and Sons. New York vol 2: 4-8, 1994.

[9] P. Gupta. Plant Pathology. Discovery Publishing House. New Delhi-vol 11(2): 23-68, 2013.

[10] V. Gwa and E. Ekefan. Host-Multi-Pathogen Warfare: Pathogen Interactions in Co-infected Plants. Frontiers in Plant Science vol 162: 1243-1248, 2017. 